\begin{tabular}{l|l} 
Notaice & e-ISSN: 2655-9404 p-ISSN: 2721-8376 \\
DOI: 10.20473/ntr.v4i3.26260
\end{tabular}

Article history: Submitted 7 April 2021; Accepted 8 June 2021; Available online 1 October 2021.

\title{
Keabsahan Pembuatan Akta Pemberian Hak Tanggungan Atas Sertipikat Hak Guna Bangunan Pada Rumah Susun yang Telah Dilakukan Perjanjian Pengikatan Jual Beli
}

\author{
Nahdlotul Fadilah \\ nahdlotulfadilah09@gmail.com \\ Universitas Airlangga
}

\begin{abstract}
Developer as seller and/or marketing agency often promising everything to buyers related to the flats settlement process, can be regulated in Sale and Purchase Engagement Agreement (hereinafter referred as "PPJB") accordance with Article 43 of Law Number 20 of 2011 concerning Flats (hereinafter referred as "Flat Law") and Regulation of Minister of Public Works and Public Housing Number 11/PRT/M/2019 concerning the Preliminary House Sale and Purchase Agreement System (hereinafter referred as "Ministerial Regulation of PUPR No. 11/PRT/M/2019"). The purpose of this research is to analyse the basis of validity of the Akta Pemberian Hak Tanggungan (Security Title Provision Deed, hereinafter referred as "APHT") on the Building Rights Certificate of the Flats (hereinafter referred as "HGB") after the PPJB has been implemented, and to analyse legal protection for buyers when the certificate of HGB is guaranteed after PPJB is carried out. The research has been determined that PPJB has classified as a conditional engagement because it has regulated the points of the agreement and has a legal consequences. The seller/developer who will enact the object of PPJB as a guarantee, basis of validity an APHT at certificate of HGB's Flats after regulated a PPJB have to qualify Article 11 of UUHT and pay attention to the provisions of Article 10 paragraph (3) alphabet d of Ministerial Regulation of PUPR No. 11/PRT/M/2019. Legal protection for buyers is a preventive legal protection and repressive legal protection.

Keywords: Validity an APHT; Certificate of HGB's Flat; PPJB; Legal Protection for Buyers.
\end{abstract}

\section{Abstrak}

Developer sebagai penjual dan/atau agen pemasaran sering kali menjanjikan segala sesuatu kepada pembeli terkait proses penyelesaian rumah susun, dituangkan dalam perjanjian pengikatan jual beli (PPJB) sesuai Pasal 43 Undang-Undang Nomor 20 Tahun 2011 tentang Rumah Susun (UU Rumah Susun) dan Peraturan Menteri Pekerjaan Umum dan Perumahan Rakyat Nomor 11/PRT/M/2019 tentang Sistem Perjanjian Pendahuluan Jual Beli Rumah (Permen PUPR No. 11/PRT/M/2019). Penelitian ini bertujuan untuk menganalisis dasar keabsahan akta pemberian hak tanggungan (APHT) atas sertipikat hak guna bangunan (HGB) pada rumah susun yang telah dilakukan PPJB dan menganalisis bentuk perlindungan hukum bagi pembeli apabila sertipikat HGB pada rumah susun dijaminkan setelah dilakukan PPJB. Dalam penelitian ini ditemukan bahwa PPJB digolongkan sebagai perjanjian bersyarat karena sudah menyentuh pokok-pokok perjanjian dan telah menimbulkan akibat hukum. Penjual/ developer yang akan menjadikan objek PPJB sebagai jaminan, dasar keabsahan pembuatan APHT atas sertipikat HGB pada rumah susun yang telah dilakukan PPJB harus memenuhi ketentuan Pasal 11 UUHT dan memperhatikan ketentuan Pasal 10 ayat (3) huruf d Permen PUPR No. 11/PRT/M/2019. Bentuk perlindungan hukum bagi pembeli satuan rumah susun dapat berupa perlindungan hukum preventif dan perlindungan hukum represif.

Kata Kunci: Keabsahan APHT; Sertipikat HGB Pada Rumah Susun; PPJB; Perlindungan Hukum Pembeli. 


\section{Pendahuluan}

Dalam Pasal 28 H ayat 1 UUD 1945, bahwa "Setiap orang berhak hidup sejahtera lahir dan batin, bertempat tinggal, dan mendapatkan lingkungan hidup yang baik dan sehat serta berhak memperoleh pelayanan kesehatan. Pemenuhan papan atau tempat tinggal yang berhubungan dengan sebidang tanah, tidak dapat setiap individu dengan semaunya untuk melakukan pemenuhan kebutuhan tempat tinggal, karena dalam Pasal 33 ayat (3) UUD 1945 menyebutkan, bahwa bumi air dan ruang angkasa, termasuk kekayaan alam yang terkandung didalamnya itu pada tingkatan tertinggi dikuasai oleh Negara, sebagai organisasi kekuasaan seluruh rakyat, dijabarkan dalam Pasal 2 ayat (1) Undang-Undang Nomor 5 Tahun 1960 tentang Peraturan Dasar Pokok-Pokok Agraria (selanjutnya disebut dengan UUPA), Negara memberikan wewenang sesuai ketentuan Pasal 2 ayat (2) UUPA.

Dalam pemenuhan kebutuhan tempat tinggal, rumah susun merupakan salah satu terobosan dalam menjawab perkembangan masyarakat yang membutuhkan tempat tinggal, karena tempat tinggal yang dibangun dengan gedung bertingkat bertujuan memaksimalkan semakin sedikitnya luas tanah yang dapat digunakan masyarakat untuk membangun tempat tinggal yang diatur dalam UndangUndang Nomor 20 Tahun 2011 tentang Rumah Susun (selanjutnya disebut dengan UU Rumah Susun). Developer sebagai penjual dan/atau agen pemasaran sering kali menjanjikan segala sesuatu kepada pembeli terkait proses penyelesaian rumah susun, proses jual beli sarusun sebelum pembangunan rumah susun selesai dapat dilakukan melalui PPJB yang dibuat di hadapan notaris, sebagaimana diatur dalam Pasal 43 UU Rumah Susun.Untuk mengoptimalkan pengaturan PPJB dalam UU Rumah Susun, Pemerintah Indonesia telah mengatur lebih detail mengenai PPJB dalam Peraturan Menteri Pekerjaan Umum dan Perumahan Rakyat Nomor 11/ PRT/M/ 2019 tentang Sitem Perjanjian Pendahuluan Jual Beli Rumah (selanjutnya disebut dengan Permen PUPR No. 11/PRT/M/2019).

Pada saat pembuatan PPJB, dalam Pasal 6 ayat (3) Permen PUPR No. 11/ PRT/M/2019 mengatur bahwa, dalam hal tanah dan/atau bangunan menjadi agunan, pelaku pembangunan menjelaskan kepada calon pembeli. Rumah 
susun yang tanah dan/atau bangunan yang menjadi agunan berupa Hak Milik, HGB pada tanah negara/hak pengelolaan, Hak Pakai pada tanah negara/ hak pengelolaan (Pasal 17 UU Rumah Susun), digunakan lembaga hukum hak tanggungan yang merupakan lembaga jaminan kebendaan sebagaimana diatur dalam Pasal 4 UU No. 4 Tahun 1996 (selanjutnya disebut UUHT) dan Pasal 3 Peraturan Menteri Agraria Dan Tata Ruang / Kepala Badan Pertanahan Nasional Nomor 5 Tahun 2020 tentang Pelayanan Hak Tanggungan Terintegrasi Secara Elektronik (selanjutnya disebut dengan Permen ATR No. 5 Tahun 2020).

Cara pemberian hak tanggungan yaitu didahului dengan janji untuk memberikan hak tanggungan sebagai jaminan pelunasan utang tertentu. Pemberian hak tanggungan dilakukan dengan pembuatan Akta Pemberian Hak Tanggungan (selanjutnya disebut dengan APHT) oleh PPAT sesuai peraturan perundang-undangan yang berlaku sebagaimana diatur dalam Pasal 10 ayat (2) UUHT. Terjadi pada kasus dalam Putusan Nomor 089/Pdt.G/2013/PN.Jkt.Bar. Ilustrasi kasus sebagai berikut:

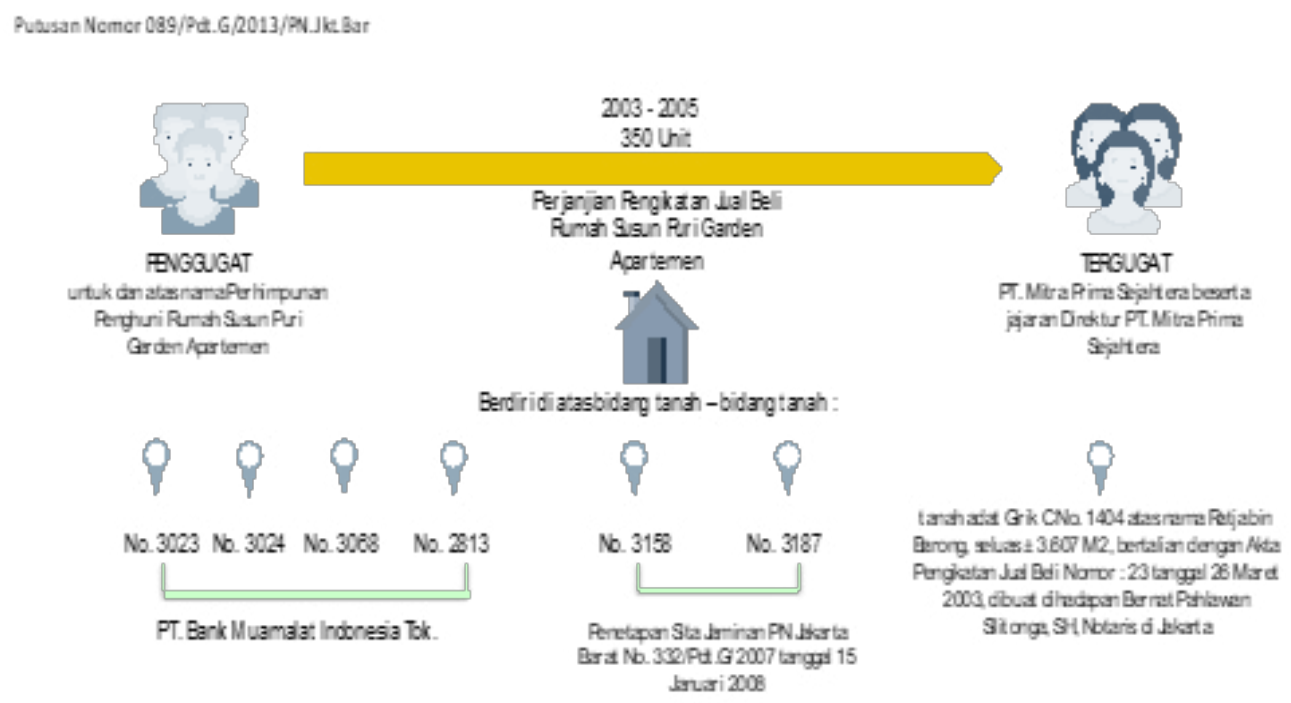

Para pihaknya antara Penggugat yang mewakili Perhimpunan Penghuni Rumah Susun Puri Garden Apartemen (selanjutnya disebut PPRS Puri Garden Apartemen) dengan Tergugat yakni PT. Mitra Prima Sejahtera (selanjutnya disebut dengan PT. MPS) beserta jajaran Direktur PT. MPS. Sekitar tahun 2003 s/d 2005, PT. MPS sebagai Developer telah memasarkan dan menjual sarusun Puri Garden 
Apartemen kepada Penggugat yang diikat dengan PPJB sarusun. Para Tergugat berjanji dan wajib untuk menyelesaikan bangunan rumah susun dan sertipikat kepemilikan atas sarusun. Rumah Susun Puri Garden Apartement yang berdiri di atas beberapa bidang tanah-bidang tanah Hak Guna Bangunan (selanjutnya disebut dengan HGB) dan tanah Girik C. Sampai dengan waktu yang disepakati Para Tergugat tidak melakukan penandatanganan AJB dan penyerahan sertipikat atas sarusun kepada para pembeli yang telah melunasi sarusun, seluruhnya berjumlah kurang lebih 350 sarusun.

Pembeli tidak memperoleh haknya akibat PT. MPS menjaminkan sertipikat HGB No. 3023, HGB No. 3024, HGB No. 3068, dan HGB No. 2813 sebagai jaminan atas perjanjian kredit dengan PT. Bank Muamalat Indonesia Tbk (selanjutnya disebut dengan Bank Muamalat) dengan dipasang hak tanggungan dan atas objek tersebut diikat pula dengan PPJB, yang mana PT. MPS sebagai penjual dan Bank Muamalat sebagai pembeli. Sertipikat HGB No. 3158 dan HGB No. 3187 diletakkan sita jaminan yaitu Tuan Soeharsono Sinto dengan Penetapan Sita Jaminan oleh Pengadilan Negeri Jakarta Barat No. 332/Pdt.G/2007 tanggal 15 Januari 2008 akibat PT. MPS tidak melunasi tagihan utangnya kepada pihak ketiga. Serta bangunan Rumah Susun Puri Garden Apartemen berdiri di atas bidang tanah Girik C No. 1404 atas nama Ratja bin Barong, seluas \pm 3.607 M2, berdasarkan akta PPJB No. 23 tanggal 26 Maret 2003, dibuat dihadapan Bernat Pahlawan Silitonga, SH, Notaris di Jakarta. Namun sampai waktu yang disepakati, PT. MPS tidak melakukan pelunasan harga tanah Girik C kepada Ahli Waris Ratja Bin Barong.

Berdasarkan kasus tersebut, terlihat bahwa Para Tergugat telah menjaminkan sertipikat kepemilikan atas tanah bersama yang digunakan sebagai dasar hak bersama secara tidak terpisah yang diatasnya berdiri rumah susun. Para Tergugat melakukannya tanpa sepengetahuan pembeli, dijaminkan kepada Bank Muamalat setelah dilakukannya PPJB antara PT. MPS dengan Pembeli Rumah Susun Puri Garden Apartemen. Berkaitan dengan kasus tersebut, pelaku pembangunan sebagai penjual rumah susun dan PPAT sebagai pembuat APHT haruslah mengerti mengenai aturan terkait pembebanan hak tanggungan atas sertipikat HGB pada 
rumah susun sesuai peraturan perundang-undangan. Sebagai pembeli harus kritis sebelum melakukan PPJB dengan pelaku pembangunan sebagai sarana sampai dapat dilakukannya peralihan yang dituangkan dalam bentuk AJB dan dibuat di hadapan PPAT.

Jurnal ini akan menganalisa mengenai dasar keabsahan akta pemberian hak tanggungan atas sertipikat hak guna bangunan pada rumah susun yang telah dilakukan perjanjian pengikatan jual beli. Serta bentuk perlindungan hukum bagi pembeli apabila sertipikat hak guna bangunan pada rumah susun dijaminkan setelah dilakukan perjanjian pengikatan jual beli

\section{Metode Penelitian}

Metode penelitian yang digunakan dengan tipe penelitian hukum normatif, karena memiliki tujuan pemecahan masalah atas isu hukum dan permasalahan hukum yang ada. Penelitian tesis ini bertujuan untuk menemukan aturan hukum, prinsip hukum maupun doktrin hukum untuk pembuatan APHT atas sertipikat HGB pada rumah susun yang telah dilakukan PPJB.

Pendekatan perundang-undangan (statute approach), pendekatan konseptual (coceptual approach); menggunakan pendekatan konsep Perjanjian Pengikatan Jual Beli (PPJB), Akta Pemberian Hak Tanggungan (APHT), sertipikat hak guna bangunan (HGB) pada rumah susun, dan perlindungan hukum bagi konsumen, dan pendekatan kasus (case approach); melalui Putusan PN Nomor 089/ Pdt.G/2013/PN.Jkt.Bar.

Analisis bahan hukum menggunakan interpretasi gramatikal atau interpretasi secara tata bahasa, yaitu diuraikan secara sederhana berdasarkan pengertian kata-kata yang ada dalam suatu pasal ketentuan undang-undang yang diperoleh dan interpretasi sistematis, yaitu interpretasi yang menghubungkan satu pasal dengan pasal-pasal yang lainnya dalam peraturan perundangundangan satu dengan yang lain, mengkaitkan UUPA, UUHT dan Permen PUPR No. 11/PRT/M/2019. 


\section{Keabsahan Akta Pemberian Hak Tanggungan (APHT)}

Akta Pemberian Hak Tanggungan wajib memuat substansi yang telah diatur dalam Pasal 11 ayat (1) UUHT, yaitu berkenaan dengan:

a. nama dan identitas pemegang dan pemberi Hak Tanggungan;

b. domisili pihak-pihak yang bersangkutan, dan apabila diantara mereka ada yang berdomisili di luar Indonesia, baginya harus pula dicantumkan suatu domisili pilihan di Indonesia, dan dalam hal domisili pilihan itu tidak dicantumkan, kantor PPAT tempat pembuatan Akta Pemberian Hak Tanggungan dianggap sebagai domisili yang dipilih;

c. penunjukan secara jelas utang atau utang-utang yang dijamin;

d. nilai tanggungan;

e. uraian yang jelas mengenai obyek Hak Tanggungan.

Substansi yang wajib ada dalam APHT yang diatur Pasal 11 ayat (1) UUHT merupakan cerminan asas spesialitas sebagai salah satu ciri unggul hak tanggungan. ${ }^{1}$ Segala janji yang dapat dicantumkan dalam APHT diatur Pasal 11 ayat (2) UUHT. Setelah dilakukan pembuatan APHT, selanjutnya dilakukan pendaftarannya. Hal ini seirama dalam penjelasan umum angka 7 UUHT yang dikatakan bahwa Proses pembebanan Hak Tanggungan dilaksanakan melalui dua tahap, yaitu:

1. Tahap pemberian Hak Tanggungan, yaitu dengan dibuatnya Akta Pemberian Hak Tanggungan

2. Tahap pendaftarannya oleh Kantor Pertanahan

Pendaftaran ini merupakan bentuk asas publisitas dalam hak kebendaan. ${ }^{2}$ Saat ini pendaftaran pembebanan hak tanggungan mengalami perubahan, untuk menerapkan pelayanan hak tanggungan yang terintegrasi secara elektronik telah ditetapkan Permen ATR No. 5 Tahun 2020. Sistem HT-el merupakan sistem yang telah disertifikasi oleh instansi yang berwenang dan tunduk pada peraturan perundang-undangan mengenai penyelenggaraan sistem dan transaksi elektronik. ${ }^{3}$

APHT harus dibuat dengan akta otentik, akta yang dibuat oleh atau

\footnotetext{
${ }^{1}$ Isnaeni Moch, Pengantar Hukum Jaminan Kebendaan (PT Revka Petra Media 2016).[226].

${ }^{2}$ ibid.

${ }^{3}$ Oemar Moechthar, Dinamika Hukum Agraria Indonesia Dalam Rangka Memperingati 70 Tahun Guru Kami, Prof. Dr. Sri Hajati, S.H., M.S. (Kencana 2020).[268].
} 
dihadapan pejabat umum. Hal ini telah diatur dalam Pasal 10 ayat (2) UUHT Jo. Pasal 44 PP No. 24 Tahun 1997 Jo. Pasal 95 Permen Agraria No. 3 Tahun 1997. Pembuatan APHT yang dibuat oleh PPAT apabila tidak memenuhi ketentuan yang diatur dalam UUJN atau Permen Agraria No. 3 Tahun 1997, konsekuensi hukumnya adalah kekuatan pembuktiannya menjadi surat di bawah tangan. APHT yang dibuat oleh PPAT tidak dapat didaftarkan. Hal tersebut dikarenakan, APHT melanggar ketentuan yang tersirat dalam UUHT yaitu dibuat dengan Akta Otentik, sehingga akibatnya asas publisitas hak tanggungan tidak terpenuhi.

\section{Pemberian Jaminan Objek Sertipikat Hak Guna Bangunan Pada Rumah Susun yang Telah Dilakukan Perjanjian Pengikatan Jual Beli}

Berdasarkan Pasal 17 UU Rumah Susun, Rumah susun dapat dibangun di atas tanah:

a. Hak Milik;

b. Hak Guna Bangunan atau Hak Pakai atas tanah Negara; dan

c. Hak Guna Bangunan atau Hak Pakai atas Hak Pengelolaan.

HGB berdasarkan Peraturan Pemerintah Nomor 40 Tahun 1996 tentang Hak Guna Usaha, Hak Guna Bangunan Dan Hak Pakai Atas Tanah (selanjutnya disebut PP No. 40 Tahun 1996), bahwa tanah yang dapat diberikan dengan HGB adalah:

a. Tanah Negara;

b. Tanah Hak Pengelolaan;

c. Tanah Hak Milik;

Rumah susun yang dibangun di atas tanah HGB atas tanah hak pengelolaan, penjual/developer memiliki kewajiban untuk menjelaskan kepada pembeli sebelum adanya kesepakatan, karena berkaitan dengan jangka waktu untuk hak atas tanah di atas tanah hak pengelolaan. HGB atas tanah hak pengelolaan tidak dapat diperpanjang secara langsung, seperti halnya HGB di atas tanah negara.

Hak Guna Bangunan dapat dijadikan jaminan utang dengan dibebani hak tanggungan, namun untuk HGB atas tanah Hak Pengelolaan harus ada 
persetujuan tertulis terlebih dahulu dari pemegang Hak Pengelolaan. ${ }^{4}$ Pasal 34 ayat (8) PP No. 40 Tahun 1996 Jo. Pasal 44 ayat (1) PP No. 24 Tahun 1997 mengatur, bahwa Pembebanan Hak Tanggungan pada hak atas tanah atau Hak Milik atas Satuan Rumah Susun, pembebanan Hak Guna Bangunan, Hak Pakai, dan Hak Sewa Untuk Bangunan atas Hak Milik, dan pembebanan lain pada hak atas tanah atau Hak Milik atas Satuan Rumah Susun yang ditentukan dengan peraturan perundang-undangan dapat didaftar jika dibuktikan dengan akta PPAT yang berwenang menurut ketentuan peraturan perundang-undangan yang berlaku. HGB atas tanah Hak Milik yang didaftarkan ke kantor pertanahan dengan akta PPAT tidak terbit bukti sertipikat kepemilikan, hanya sebatas pemberitahuan, untuk itu HGB atas tanah Hak Milik tidak bisa menjadi jaminan utang yang dibebani hak tanggungan. Subjek hukum yang berwenang melakukan perbuatan hukum dalam hak tanggungan terhadap obyek hak tanggungan berupa HGB adalah pemegang HGB, hal ini diatur dalam Pasal 8 UUHT.

Jual beli dalam proses rumah susun, dapat dilakukan jual beli sarusun sebelum pembangunan rumah susun selesai melalui PPJB yang dibuat dengan akta Notaris dan dapat dilanjutkan dengan peralihan hak setelah pembangunan rumah susun selesai dilakukan yang dituangkan dalam AJB. Terdapat 2 (dua) pendapat terkait PPJB yakni PPJB sebagai perjanjian pendahuluan atau PPJB sebagai perjanjian yang tergolong perjanjian bersyarat. Perjanjian Pengikatan Jual Beli digolongkan sebagai perjanjian bersyarat dikarenakan sudah menyentuh pokok-pokok perjanjian dan telah menimbulkan akibat hukum atau dalam arti jelas, telah diatur mengenai hubungan hukum di antara para pihak dan telah jelas pula hak dan kewajiban masing-masing pihaknya. ${ }^{5}$ Membuat suatu perjanjian harus memenuhi unsur-unsur dari Pasal 1320 BW mengenai syarat sah terjadinya suatu perjanjian, yaitu:

1. Sepakat mereka yang mengikatkan dirinya;

\footnotetext{
${ }^{4}$ Urip Santoso, 'Hak Guna Bangunan Atas Hak Pengelolaan' (2011) ADIL:Jurnal Hukum.[293].

${ }^{5}$ Kadek Deddy Permana, 'Keabsahan Pre Project Selling' (Universitas Airlangga 2020).[28].
} 
2. Kecakapan untuk membuat suatu perikatan;

3. Suatu hal tertentu;

4. Suatu sebab yang diperbolehkan.

2 (dua) syarat yang pertama merupakan syarat-syarat subjektif karena mengatur syarat sah subjek yang membuat perjanjian, apabila syarat tidak sah dapat dibatalkan. Sedangkan 2 (dua) syarat yang selanjutnya merupakan syarat-syarat objektif karena mengatur syarat sah perjanjiannya berkaitan dengan objek dalam pembuatan perjanjian, apabila syarat tidak sah maka akan batal demi hukum.

Perjanjian Pengikatan Jual Beli dalam rumah susun diatur dalam Pasal 42 ayat (3) Jo. Pasal 43 UU Rumah Susun. Pengaturan PPJB dalam Pasal 10 ayat (2) Permen PUPR No. 11/PRT/M/2019, bahwa Status kepemilikan tanah, dibuktikan dengan sertipikat hak atas tanah yang diperlihatkan kepada calon pembeli pada saat penandatanganan PPJB. Pasal 10 ayat (3) Permen PUPR No. 11/PRT/M/2019, Untuk hal yang diperjanjikan paling sedikit terdiri atas:

a. kondisi Rumah;

b. prasarana, sarana, dan utilitas umum yang menjadi informasi pemasaran

c. penjelasan kepada calon pembeli mengenai materi muatan PPJB; dan

d. status tanah dan/atau bangunan dalam hal menjadi agunan, pelaku pembangunan menjelaskan kepada calon pembeli.

Berdasarkan Pasal 10 ayat (3) huruf d Permen PUPR No. 11/PRT/M/2019 disebutkan, bahwa Untuk hal yang diperjanjikan juga perlu diatur status tanah dan/atau bangunan dalam hal menjadi agunan, pelaku pembangunan menjelaskan kepada calon pembeli. Berdasarkan pengaturan ini menunjukkan bahwa tanah dan/atau bangunan menjadi agunan atau akan dijadikan agunan harus meminta persetujuan kepada pembeli, mengingat PPJB sebagai perjanjian pengikatan yang digolongkan sebagai perjanjian bersyarat karena sudah menyentuh pokok-pokok perjanjian dan telah menimbulkan akibat hukum. Pemberian jaminan berupa obyek sertipikat HGB pada rumah susun yang telah dilakukan PPJB, maka sebelum proses pembuatan APHT dilakukan, pembeli memiliki hak untuk menyetujui atau tidak. Inilah yang harus diperhatikan penjual/developer sebagai keabsahan menjaminkan sertipikat HGB pada rumah susun setelah dilakukan PPJB dengan pembuatan APHT terlebih dahulu. Karena janji-janji yang terdapat dalam APHT 
yang didaftarkan akan mengikat pihak ketiga, objek yang sudah dibebani hak tanggungan, maka kewenangan pemberi hak tanggungan menjadi terbatas.

\section{Pembatalan Akta Pemberian Hak Tanggungan}

Pembatalan APHT yang merupakan akta PPAT, dibuat dengan memenuhi syarat sah perjanjian berdasarkan Pasal 1320 BW atas kesepakatan para pihak yang melakukan perbuatan hukum yang dalam hal ini akan dilakukan pembebanan hak tanggungan, serta akta PPAT yang berkaitan dengan pendaftaran tanah tidak terdapat hubungan antara yang memerintah (penguasa) dengan yang diperintah (rakyat). Philipus M. Hadjon mengatakan dalam konsep hukum administrasi, pelaksanaan fungsi pemerintahan berada dalam hubungan antara yang memerintah dan yang diperintah. ${ }^{6}$ Untuk itu akta PPAT bukan merupakan instrumen pemerintahan, bukan norma pemerintahan, bukan bagian dari keputusan TUN. Hal ini berkaitan dengan ketentuan Pasal 1 angka 4 UU Nomor 5 Tahun 1986 Jo. UU Nomor 9 Tahun 2004 tentang Peradilan Tata Usaha Negara (selanjutnya disebut UU PTUN), dalam pengaturan tersebut menjelaskan bahwa pengadilan TUN tidak berwenang menangani sengketa akta PPAT karena akta PPAT bukan bagian dari keputusan tata usaha negara, maka sengketa akta PPAT kewenangannya jelas ada pada Peradilan Umum karena sengketa tersebut terjadi di antara para pihak yang membuat perjanjian.

Pembuatan APHT yang terdapat salah satu pihak memiliki itikad buruk atau akta cacat hukum dalam proses pembuatannya, serta pihak yang dirugikan mengajukan pembatalan akta dengan mengajukan gugatan ke peradilan umum dan mendapat putusan pengadilan kekuatan hukum tetap. Peradilan umum hanya berwenang menguji atas APHT yang menjadi dasar mengurus sertipikat sah atau tidak. Akan tetapi untuk APHT yang sudah didaftarkan secara sempurna sampai dengan diterbitkannya sertipikat hak tanggungan. Pembatalan sertipikat hak tanggungan yang merupakan produk Keputusan Tata Usaha Negara (KTUN),

\footnotetext{
${ }^{6}$ Philipus M. Hadjon, 'Eksistensi Dan Fungsi Pejabat Pembuat Akta Tanah (PPAT) Serta Figur Hukum Akta PPAT’ (1996) Fakultas Hukum Universitas Airlangga.[3].
} 
berdasarkan Pasal 1 angka 3 UU PTUN, bahwa Keputusan Tata Usaha Negara adalah suatu penetapan tertulis yang dikeluarkan oleh Badan atau Pejabat Tata Usaha Negara yang berisi tindakan hukum Tata Usaha Negara yang berdasarkan peraturan perundang-undangan yang berlaku, yang bersifat konkret, individual, dan final, yang menimbulkan akibat hukum bagi seseorang atau badan hukum perdata. Keabsahan KTUN yang berwenang menguji adalah Peradilan Tata usaha negara (PTUN) dapat berupa keputusan pembatalan sertipikat oleh pejabat yang berwenang, sesuai dengan ketentuan Pasal 47 UU PTUN, bahwa Pengadilan bertugas dan berwenang memeriksa, memutus, dan menyelesaikan sengketa Tata Usaha Negara.

Sesuai Pasal 124 Peraturan Menteri Negara Agraria/Kepala Badan Pertanahan Nasional Nomor 9 Tahun 1999 tentang Tata Cara Pemberian Dan Pembatalan Hak Atas Tanah Negara Dan Hak Pengelolaan (selanjutnya disebut Permen Agraria No. 9 Tahun 1999), bahwa Keputusan pembatalan hak atas tanah karena melaksanakan putusan pengadilan yang telah memperoleh kekuatan hukum tetap diterbitkan atas permohonan yang berkepentingan. Amar putusan pengadilan yang telah memperoleh kekuatan hukum tetap dinyatakan batal atau tidak mempunyai kekuatan hukum atau yang pada intinya sama dengan itu. Selanjutnya berdasarkan Pasal 125 Permen Agraria No. 9 Tahun 1999, bahwa Permohonan pembatalan hak karena melaksanakan putusan pengadilan yang telah memperoleh kekuatan hukum tetap dapat diajukan langsung kepada Menteri atau Kepala Kantor Wilayah atau melalui Kepala Kantor Pertanahan.

Konsekuensinya dariadanya pembatalan ini yaitu pemegang hak tanggungan berubah kedudukan dari kreditor preferen menjadi kreditor konkuren, bahkan kreditor yang demikian tidak memiliki hak jaminan yang kuat dan kepastian hukum akan dilunasinya utang debitor. Dimana kreditor ini tanpa ada hak istimewa ataupun hak separatis yang melindungi kepastian pelunasan piutangnya. ${ }^{7}$ Dengan pembatalan tersebut menyebabkan kedudukan kreditor menjadi kreditor 
konkuren atau kreditor yang tidak didahulukan dalam pembayaran piutangnya karena kedudukannya sederajat dengan kreditur konkuren lainnya.

\section{Perlindungan Hukum Bagi Pembeli Setelah Dilakukan Perjanjian Pengikatan Jual Beli}

Hukum diciptakan sebagai suatu sarana atau instrumen untuk mengatur hak-hak dan kewajiban-kewajiban subjek hukum, baik orang maupun badan hukum untuk dapat menjalankannya dengan baik dan mendapatkan haknya secara wajar. Menurut Philipus M. Hadjon: ${ }^{8}$

"Perlindungan hukum adalah perlindungan akan harkat dan martabat, serta pengakuan terhadap hak-hak asasi manusia yang dimiliki oleh subyek hukum berdasarkan ketentuan hukum dari kewenangan-kewenangan atau sebagai kumpulan peraturan atau kaidah yang akan dapat melindungi suatu hal dari hal lainnya. Berkaitan dengan konsumen, berarti hukum memberikan perlindungan terhadap hak-hak pelanggan dari sesuatu yang mengakibatkan tidak terpenuhinya hak-hak tersebut".

Bagi konsumen, informasi tentang barang dan/atau jasa merupakan kebutuhan pokok sebelum menggunakan sumber dananya untuk mengadakan transaksi konsumen tentang barang/jasa. Dengan transaksi konsumen dimaksudkan diadakannya hubungan hukum (jual beli, beli-sewa, sewa menyewa, pinjam meminjam, dan sebagainya) tentang produk konsumen dengan pelaku usaha itu. ${ }^{9}$ Selanjutnya Philipus M. Hadjon mengemukakan bahwa sarana perlindungan hukum terdapat dua macam, yaitu: ${ }^{10}$

\section{a. Perlindungan Hukum Preventif}

Perlindungan hukum preventif bertujuan untuk melakukan pencegahan adanya pelanggaran atau sengketa yang kemungkinan terjadi di kemudian hari, hal ini diharapkan mencegah atau menghindarkan seorang subyek hukum untuk melakukan suatu tindakan negatif. ${ }^{11}$ Perlindungan hukum preventif ini diterapkan dengan adanya Undang-Undang atau peraturan perundang-undangan

\footnotetext{
${ }^{8}$ Philipus M. Hadjon, Pelindungan Hukum Bagi Rakyat Indonesia (Bina Ilmu 1987).[25].

${ }^{9}$ Celine Tri Siwi Kristiyani, Hukum Perlindungan Konsumen (Sinar Grafika 2009).[70].

${ }^{10}$ Philipus M. Hadjon, Op. Cit.[30].

${ }^{11}$ Loc. Cit.
} 
yang dimaksudkan untuk memberikan batasan-batasan dalam melakukan suatu kewajiban dan mencegah adanya pelanggaran. Dengan adanya perlindungan hukum preventif, pemerintah diharapkan untuk bertindak lebih hati-hati dalam mengambil suatu keputusan. ${ }^{12}$

Bentuk perlindungan hukum preventif bagi pembeli setelah dilakukan PPJB, regulator telah memfalisitasi perlindungan hukum terhadap pembeli hanya dapat diberikan kepada pembeli yang beritikad baik sesuai Pasal 1338 ayat (3) BW. Hal ini telah termuat dalam Surat Edaran Mahkamah Agung Nomor 4 Tahun 2016 tentang Pemberlakuan Rumusan Hasil Rapat Pleno Kamar Mahkamah Agung Tahun 2016 Sebagai Pedoman Pelaksanaan Tugas Bagi Pengadilan (selanjutnya disebut SEMA No. 4 Tahun 2016), bahwa Kriteria pembeli yang beritikad baik yang perlu dilindungi berdasarkan Pasal 1338 ayat (3) BW adalah sebagai berikut:

a. Melakukan jual beli atas objek tanah tersebut dengan tata cara/prosedur dan dokumen yang sah sebagaimana telah ditentukan peraturan perundangundangan yaitu:

- Pembelian tanah melalui pelelangan umum atau;

- Pembelian tanah di hadapan Pejabat Pembuat Akta Tanah (sesuai dengan ketentuan Peraturan Pemerintah Nomor 24 tahun 1997 atau;

- Pembelian terhadap tanah milik adat / yang belum terdaftar yang dilaksanakan menurut ketentuan hukum adat yaitu:

- dilakukan secara tunai dan terang (di hadapan / diketahui Kepala Desa/Lurah setempat).

- didahului dengan penelitian mengenai status tanah objek jual beli dan berdasarkan penelitian tersebut menunjukkan bahwa tanah objek jual beli adalah milik penjual.

- Pembelian dilakukan dengan harga yang layak.

b. Melakukan kehati-hatian dengan meneliti hal-hal berkaitan dengan objek tanah yang diperjanjikan antara lain:

- Penjual adalah orang yang berhak/memiliki hak atas tanah yang menjadi objek jual beli, sesuai dengan bukti kepemilikannya, atau;

- Tanah/objek yang diperjualbelikan tersebut tidak dalam status disita, atau;

- Tanah objek yang diperjualbelikan tidak dalam status jaminan/hak tanggungan, atau; 
- Terhadap tanah yang bersertipikat, telah memperoleh keterangan dari BPN dan riwayat hubungan hukum antara tanah tersebut dengan pemegang sertipikat.

Sesuai SEMA No. 4 Tahun 2016, seseorang dapat disebut sebagai pembeli yang beritikad baik apabila pembeli dalam proses jual beli sesuai peraturan perundangundangan dan melakukan kehati-hatian dengan meneliti tanah yang akan dibeli sebagai objek jual beli terkait data fisik maupun data yuridis.

Pengaturan Pasal 1338 (3) BW, yang menetapkan bahwa persetujuan harus dilaksanakan dengan iktikad baik, maksudnya perjanjian itu dilaksanakan menurut kepatutan dan keadilan. Pengertian iktikad baik dalam dunia hukum mempunyai arti yang lebih luas dari pada pengertian sehari-hari. ${ }^{13}$ Menurut J.M. van Dunne, daya berlaku iktikad baik, meliputi seluruh proses kontrak yang terbagi dalam tiga fase, yakni fase pra kontrak (precontractuele fase), fase pelaksanaan kontrak (contractuele fase), dan fase pasca kontrak (postcontractuele fase). ${ }^{14}$ Sebagaimana dipahami bahwa pemahaman substansi iktikad baik dalam Pasal 1338 ayat (3) BW tidak harus diinterpretasikan secara gramatikal, bahwa iktikad baik hanya muncul sebatas pada tahap pelaksanaan kontrak. Iktikad baik harus dimaknai dalam keseluruhan proses kontraktual. Dengan demikian, fungsi iktikad baik dalam Pasal 1338 (3) BW mempunyai sifat dinamis melingkupi keseluruhan proses kontrak tersebut. ${ }^{15}$

Sehubungan dengan fungsi iktikad baik dalam Pasal 1338 (3) BW, menurut beberapa sarjana antara lain P. L. Werry, Arthur S. Hartkamp dan Marianne M. M. Tillem, terdapat 3 (tiga) fungsi utama iktikad baik, yaitu: ${ }^{16}$

1. Fungsi yang mengajarkan bahwa kontrak harus ditafsirkan menurut iktikad baik (iktikad baik sebagai asas hukum umum), artinya kontrak harus ditafsirkan secara patut dan wajar (fair);

2. Fungsi menambah atau melengkapi (aanvullende werking van de geode trouw),

\footnotetext{
${ }^{13}$ Agus Yudha Hernoko, Hukum Perjanjian Asas Proporsionalitas Dalam Kontrak Komersial (Kencana Prenada Media Group 2014).[135].

14 ibid.[136].

15 ibid.[139].

${ }^{16}$ ibid.[139-140].
} 
artinya iktikad baik dapat menambah isi atau kata-kata perjanjian apabila terdapat hak dan kewajiban yang timbul diantara para pihak tidak secara tegas dinyatakan dalam kontrak;

3. Fungsi membatasi atau meniadakan (beperkende en derogerende werking van de goede trouw), artinya fungsi ini hanya dapat diterapkan apabila terdapat alasan-alasan yang amat penting (alleen in spreekende gevallen).

Memang diakui bahwa untuk memahami iktikad baik bukan hal yang mudah. Pada kenyataannya iktikad baik acap kali tumpang-tindih dengan kewajaran dan kepatutan (redelijkheid en billijkheid; reasonableness and equity). Oleh karena itu dalam praktik pengadilan, iktikad baik dan kepatutan dipahami sebagai asas atau prinsip yang saling melengkapi. ${ }^{17}$

Setelah segala kehati-hatian yang dilakukan oleh pembeli sebelum melakukan transaksi peralihan hak atas tanah, apabila dikemudian hari terdapat kerugian yang diderita oleh pembeli yang memenuhi kriteria pembeli beritikad baik atas perbuatan penjual, maka hukum harus memberikan perlindungan terhadap pembeli yang dirugikan. Perlindungan hukum preventif tersebut, antara lain:

1. Pasal 98 UU Rumah Susun, bahwa Pelaku pembangunan dilarang membuat perjanjian pengikatan jual beli:

a. yang tidak sesuai dengan yang dipasarkan; atau

b. sebelum memenuhi persyaratan kepastian atas:

- status kepemilikan tanah;

- kepemilikan IMB;

- ketersediaan prasarana, sarana, dan utilitas umum;

- keterbangunan paling sedikit 20\% (dua puluh persen); dan

- hal yang diperjanjikan.

2. Pasal 12 Permen PUPR No. 11/PRT/M/2019, bahwa:

(1) Calon pembeli berhak mempelajari PPJB sebelum ditandatangani paling kurang 7 (tujuh) hari kerja.

(2) PPJB ditandatangani oleh calon pembeli dan pelaku pembangunan yang dibuat di hadapan notaris.

3. Serta mengingat Pasal 1320 BW yang mengatur syarat sah terjadinya suatu perjanjian, yaitu:

1. Sepakat mereka yang mengikatkan dirinya;

2. Kecakapan untuk membuat suatu perikatan;

${ }^{17}$ ibid.[40]. 
3. Suatu hal tertentu;

4. Suatu sebab yang diperbolehkan.

4. SEMA No. 4 Tahun 2016, namun hanya sebagai pedoman hakim dalam memberikan putusan karena yang diatur dalam SEMA No. 4 Tahun 2016 terkait pembeli beritikad baik tidak bersifat limitatif, terdapat kriteria itikad baik yang lain.

Maka PPJB tersebut merupakan perjanjian yang menimbulkan perikatan dan akibat hukum apabila tidak terpenuhinya isi dari perjanjian sebagai bentuk perlindungan hukum.

\section{b. Perlindungan Hukum Represif Dan Penyelesaian Sengketa}

Perlindungan hukum represif memiliki tujuan untuk menyelesaikan suatu sengketa. Penanganan di pengadilan merupakan bentuk perlindungan hukum represif. ${ }^{18}$ Perlindungan hukum represif hanya dapat dilaksanakan apabila telah terjadi suatu sengketa. Perlindungan hukum represif ialah perlindungan terakhir berbentuk suatu sanksi seperti denda, penjara, maupun hukuman tambahan lain yang diberikan setelah terjadi sengketa atau terjadinya pelanggaran. ${ }^{19}$ Sanksi merupakan perlindungan terakhir sebagai bentuk perlindungan hukum represif yang diberikan kepada pembeli yang beritikad baik. Dalam ketentuan Pasal 117 UU Rumah Susun disebutkan bahwa:

(1) Dalam hal perbuatan sebagaimana dimaksud dalam Pasal 109 sampai dengan Pasal 116 dilakukan oleh badan hukum, maka selain pidana penjara dan denda terhadap pengurusnya, pidana dapat dijatuhkan terhadap badan hukum berupa pidana denda dengan pemberatan 3 (tiga) kali dari pidana denda terhadap orang.

(2) Selain pidana denda, badan hukum dapat dijatuhi pidana tambahan berupa:

a. pencabutan izin usaha; atau

b. pencabutan status badan hukum.

Penyelesaian sengketa dapat dilakukan melalui jalur litigasi maupun nonlitigasi. Penyelesaian sengketa melalui non-litigasi sesuai Pasal 1 angka 10 UndangUndang Nomor 30 Tahun 1999 tentang Arbitrase dan Alternatif Penyelesaian Sengketa, bahwa Alternatif Penyelesaian Perkara (Alternatif Dispute Resolution)

${ }^{18}$ Handri Raharjo, Sistem Hukum Indonesia: Ketentuan-Ketentuan Hukum Indonesia Dan Hubungannya Dengan Hukum Internasional (Pustaka Yustisia 2018).[21-22].

${ }^{19}$ Philipus M. Hadjon, Op.Cit.[30]. 
adalah lembaga penyelesaian sengketa atau beda pendapat melalui prosedur yang disepakati para pihak yakni penyelesaian di luar pengadilan dengan cara konsultasi, negosiasi, mediasi, atau penilaian para ahli. Penyelesaian sengketa melalui non-litigasi mencapai kesepakatan mengenai bentuk dan besarnya ganti rugi dan/atau mengenai tindakan tertentu untuk menjamin tidak akan terjadi kembali atau tidak akan terulang kembali kerugian yang diderita oleh konsumen. Penyelesaian sengketa melalui litigasi dilakukan pada saat penyelesaian sengketa melalui non-litigasi tidak berhasil, penyelesaian sengketa melalui litigasi berupa gugatan perdata, gugatan atas kerugian yang dialami pembeli baik berupa kerugian materiil atau immateriil, dapat dilakukan gugatan atas dasar wanprestasi atau perbuatan melanggar hukum.

\section{Analisis Putusan Dalam Konsep Hukum Jaminan dan Hukum Pertanahan Indonesia \\ Dalam Konsep Hukum Jaminan}

Berdasarkan Putusan PN Jakarta Barat Nomor 089/Pdt.G/2013/PN.Jkt.Bar, dikaji dengan perspektif hukum jaminan dalam hal memberi kewenangan kepada PPRS Puri Garden Apartemen untuk menyelesaikan perjanjian kredit yang diberi jaminan hak tanggungan antara PT. MPS kepada Bank Muamalat, dengan diadakan Perjanjian Kesepakatan Bersama antara PPRS Puri Garden Apartemen dengan Bank Muamalat, bahwa para penggugat bersedia menyelesaikan pembayaran perjanjian kredit yang dilakukan oleh PT. MPS dengan Bank Muamalat. Penulis kurang setuju dengan Hakim dalam memberikan pertimbangan dan putusan ini, karena dalam hal piutang yang dijamin dengan hak tanggungan beralih harus memenuhi ketentuan dari Pasal 16 UUHT.

Peralihan piutang dari PT. MPS kepada Para Penggugat tidak berhenti sampai dibuatnya akta Perjanjian Kesepakatan Bersama antara PPRS Puri Garden Apartemen dengan Bank Muamalat, selanjutnya harus dilakukan permohonan pelayanan HT-el sesuai ketentuan dalam Pasal 9 ayat (1) dan ayat (2) Permen ATR No. 5 Tahun 2020. Dengan demikian piutang yang dijamin dengan hak tanggungan 
antara PT. MPS dengan Bank Muamalat yang beralih dari kepada PPRS Puri Garden Apartemen, atas dasar akta Perjanjian Kesepakatan Bersama antara Para Penggugat dengan Bank Muamalat dan dilakukan permohonan pelayanan HT-el, maka peralihan tersebut menjadi sempurna.

Setelah pembuatan PPJB antara PT. MPS dan pembeli, HGB pada rumah susun dijadikan agunan dan dijamin dengan hak tanggungan oleh PT. MPS kepada Bank Muamalat, namun PT. MPS tidak meminta persetujuan kepada pembeli atas HGB pada rumah susun dijaminkan kepada Bank Muamalat. Pembuatan PPJB dalam perkara ini dilakukan pada tahun 2003 sampai dengan 2005. Pengaturan rumah susun diatur dalam Undang-Undang Nomor 16 Tahun 1985 tentang Rumah Susun, dalam peraturan ini tidak mengatur terkait PPJB dan pembuatan PPJB diatur dalam Keputusan Menteri Negara Perumahan Rakyat Nomor : 09 /KPTS/M/1995 tentang Pedoman Pengikatan Jual Beli Rumah, dimana pembuatan PPJB pada rumah susun dapat dilakukan dengan perjanjian di bawah tangan dan tidak mengharuskan membuat di hadapan notaris, tidak ada aturan yang melarang bahwa penjual/ developer menjaminkan tanah pada rumah susun setelah pembuatan PPJB. Namun atas perubahan dalam rumah susun yaitu Undang-Undang Nomor 20 Tahun 2011 tentang Rumah Susun mengatur terkait pembuatan PPJB dapat dilakukan di hadapan notaris, hal ini diatur dalam Pasal 43 UU Rumah Susun.

Perubahan UU Rumah Susun pula tidak mengatur bahwa penjual/developer tidak boleh menjaminkan tanah pada rumah susun setelah pembuatan PPJB. Untuk itu PT. MPS masih leluasa untuk mengagunkan HGB pada rumah susun, karena dalam Pasal 8 UUHT. Selama PT. MPS memenuhi ketentuan UUHT dalam menjaminkan HGB, maka perjanjian accessoir akan ada dan dianggap sempurna. Pemerintah mengatur lebih detail untuk mengoptimalkan pengaturan mengenai PPJB sarusun Pasal 43 UU Rumah Susun yakni dalam Permen PUPR No. 11/ PRT/M/2019 pada Pasal 10 sampai dengan Pasal 13. Untuk Pasal 10 ayat (3) huruf d Permen PUPR No. 11/PRT/M/2019 disebutkan untuk hal yang diperjanjikan juga perlu diatur status tanah dan/atau bangunan dalam hal menjadi agunan, pelaku pembangunan menjelaskan kepada calon pembeli. 
Penjual/developer sebagai pemegang hak atas tanah atau hak milik atas sarusun sebelum dialihkan kepada pemilik rumah susun, penjual/developer memiliki kekuasaan untuk menjaminkan hak atas tanah atau hak milik atas sarusun tersebut. Namun berdasarkan Pasal 10 ayat (3) huruf d Permen PUPR No. 11/PRT/M/2019 menunjukkan bahwa tanah dan/atau bangunan menjadi agunan atau akan dijadikan agunan harus meminta persetujuan kepada pembeli, mengingat PPJB sebagai perjanjian pengikatan yang digolongkan sebagai perjanjian bersyarat karena sudah menyentuh pokok-pokok perjanjian dan membawa konsekuensi hukum bagi pihak yang tidak melaksanakannya/ melanggar isi dari perjanjian yang disepakati, meskipun PPJB belum mengalihkan kepemilikan atas sarusun.

Dalam perkara ini, pembuatan PPJB antara penjual/developer dan pembeli sebagai perjanjian bersyarat merupakan sah karena penjual dan pembeli menyatakan setuju tentang benda dan harga, pada saat itu pula perjanjian mengikat secara sah bagi kedua belah pihak. Penjual/developer yakni PT. MPS yang menjaminkan tanah HGB pada rumah susun kepada Bank Muamalat yang terlebih dahulu dibuatkan APHT, APHT tersebut tidak sah karena dalam pembuatannya tanpa persetujuan pembeli terlebih dahulu. Sehingga pembeli dapat mengajukan gugatan untuk membatalkan APHT antara PT. MPS dan Bank Muamalat ke peradilan umum. Hakim dapat memberikan pertimbangan hukum atas bukti-bukti di persidangan dan memberi putusan bahwa APHT yang menjadi dasar mengurus sertipikat tidak sah.

Dalam perkara ini, Hakim memberikan putusan bahwa menyatakan Akta Perjanjian Pengikatan Jual Beli (PPJB) No. 30 tanggal 23 Desember 2005 dan Akta Pernyataan Rapat Umum Pemegang Saham Perseroan Terbatas PT. Mitra Prima Sejahtera No.29 tanggal 23 Desember 2005 masing-masing dibuat di hadapan Hotman Syukur Nasution, SH., Notaris di Jakarta adalah mempunyai kekuatan hukum yang sah. Penulis tidak setuju dengan putusan Hakim untuk Akta Perjanjian Pengikatan Jual Beli (PPJB) No. 30 tanggal 23 Desember 2005 adalah mempunyai kekuatan hukum yang sah karena Akta PPJB antara PT. 
MPS dengan Bank Muamalat yang sebelumnya telah dilakukan penjaminan atas HGB pada rumah susun tanpa persetujuan pembeli terlebih dahulu adalah batal demi hukum, pembuatan PPJB antara PT. MPS dan Bank Muamalat telah melanggar dari syarat sah perjanjian Pasal 1320 angka 4 tentang suatu sebab yang diperbolehkan. Perjanjian kredit yang diberi jaminan HGB pada rumah susun telah melanggar asas itikad baik dan kepatutan. Penulis setuju dengan putusan Hakim untuk Akta Pernyataan Rapat Umum Pemegang Saham Perseroan Terbatas PT. Mitra Prima Sejahtera No.29 tanggal 23 Desember 2005 mempunyai kekuatan hukum yang sah, karena Rapat Umum Pemegang Saham Perseroan Terbatas PT. MPS telah memenuhi ketentuan dari Undang-Undang No. 40 Tahun 2007 tentang Perseroan Terbatas.

\section{Dalam Konsep Hukum Pertanahan Indonesia}

Berdasarkan Putusan PN Jakarta Barat Nomor 089/Pdt.G/2013/PN.Jkt. Bar, dilakukan kajian dengan perspektif hukum pertanahan Indonesia. Bangunan Rumah Susun Puri Garden Apartemen berdiri di atas bidang tanah - bidang tanah HGB No. 3023, HGB No. 3024, HGB No. 3068, HGB No. 2813, HGB No. 3187 dan HGB No. 3158, seluruhnya atas nama PT. MPS. Serta bidang tanah Girik C No. 1404 atas nama Ratja bin Barong, seluas \pm 3.607 M2, berdasarkan PPJB No : 23 tanggal 26 Maret 2003, namun belum dibayar lunas oleh Perseroan PT. MPS kepada ahli waris pemilik tanah, menyebabkan belum ada peralihan hak atas tanah adat Girik $\mathrm{C}$ dari pemilik tanah girik kepada PT. MPS. PT. Mitra Prima Sejahtera sebagai subjek hukum yaitu badan hukum Indonesia dapat mempunyai HGB sesuai ketentuan Pasal 36 UUPA Jo. Pasal 19 PP No. 40 Tahun 1996, bahwa Yang dapat mempunyai hak guna bangunan ialah:
a. warganegara Indonesia;
b. badan hukum yang didirikan menurut hukum Indonesia dan berkedudukan di Indonesia.

Berdasarkan Pasal 39 UUPA Jo. Pasal 33 PP No. 40 Tahun 1996, bahwa Hak guna bangunan dapat dijadikan jaminan utang dengan dibebani hak tanggungan. 
Hak Guna Bangunan dapat dijadikan jaminan utang dengan dibebani Hak Tanggungan, namun untuk HGB atas tanah Hak Pengelolaan harus ada persetujuan tertulis terlebih dahulu dari pemegang Hak Pengelolaan. ${ }^{20}$ HGB atas tanah Hak Milik yang didaftarkan ke kantor pertanahan dengan akta PPAT tidak terbit bukti sertipikat kepemilikan, hanya sebatas pemberitahuan, untuk itu HGB atas tanah Hak Milik tidak bisa menjadi jaminan utang yang dibebani hak tanggungan.

Tanah Girik C No. 1404 atas nama Ratja bin Barong, seluas \pm 3.607 M2, merupakan tanah hak milik adat. Setelah lahirnya UUPA pada tanggal 24 September 1960, Pasal 19 UUPA mengatur bahwa:

(1) Untuk menjamin kepastian hukum, oleh pemerintah diadakan pendaftaran tanah di seluruh wilayah RI menurut ketentuan yang diatur dengan Peraturan Pemerintah.

(2) Pendaftaran tanah tersebut meliputi kegiatan:

a. pengukuran, pemetaan dan pembukuan tanah;

b. pendaftaran hak-hak atas tanah dan perlihan hak- hak tersebut;

c. pemberiaan surat-surat tanda bukti hak yang berlaku sebagai alat pembuktian yang kuat.

(3) Pendaftaran tanah diselenggarakan mengingat keadaan Negara dan masyarakat, keperluan lalu lintas sosial, ekonomi serta kemungkinan penyelengaraannya menurut pertimbangan Menteri.

(4) Biaya pendaftaran tanah akan diatur dengan Peraturan Pemerintah dengan ketentuan bagi rakyat yang tidak mampu dibebaskan dari pembayaran biaya.

Pendaftaran tanah dilakukan atas dasar bukti kepemilikan, sesuai dengan penjelasan Pasal 24 ayat (1) PP No. 24 Tahun 1997, bahwa Bukti kepemilikan itu pada dasarnya terdiri dari bukti kepemilikan atas nama pemegang hak pada waktu berlakunya UUPA dan apabila hak tersebut kemudian beralih, bukti peralihan hak berturut-turut sampai ke tangan pemegang hak pada waktu dilakukan pembukuan hak. Permasalahan sering kali ditemukan dalam pendaftaran hak atas tanah yang lama, dalam perkara ini hak atas tanah yang lama berupa tanah girik. Untuk itu diberikan kemudahan melakukan pendaftaran tanah dengan pembuktian tanahtanah hak milik adat berdasarkan bukti pengenaan pajak tanah sebelum UUPA yang diatur dalam Pasal 76 ayat (1) huruf f Permen Agraria No. 3 Tahun 1997, 
bahwa Petuk Pajak Bumi/Landrente, girik, pipil, kekitir dan Verponding Indonesia sebelum berlakunya Peraturan Pemerintah Nomor 10 Tahun 1961.

Perjanjian Pengikatan Jual Beli tanah Girik C No. 1404 atas nama Ratja bin Barong, antara PT. MPS dengan ahli waris pemilik tanah, apabila PT. MPS membayar lunas tanah adat girik kepada ahli waris Ratja Bin Barong serta dilakukan peralihan hak melalui akta AJB yang dibuat oleh PPAT yang berwenang, berdasarkan Pasal 37 PP No. 24 Tahun 1997 memberikan langkah hukum kepada PT. MPS sebagai pembeli tanah hak milik adat dengan bukti surat girik yang belum bersertipikat untuk dilakukan perolehan sertipikat dari Kantor Pertanahan langsung atas nama PT. MPS melalui proses penegasan konversi sekaligus pencatatan peralihan haknya.

Kelengkapan data surat bukti kepemilikan tanah adat sebagai penentu proses pendaftaran sertipikat, namun PT. MPS tidak dapat memperoleh tanah tersebut menjadi tanah Hak Milik, karena PT. MPS sebagai badan hukum tidak termasuk subjek hukum yang dapat memperoleh Hak Milik sesuai ketentuan dalam Pasal 21 UUPA.Sehingga hak atas tanah yang dapat diperoleh PT. MPS yaitu HGB, sesuai dengan ketentuan Pasal 36 UUPA Jo. Pasal 19 PP No. 40 Tahun 1996.

Pertimbangan hukum terkait kedudukan Pengurus PPRS Puri Garden Apartemen Kotamadya Jakarta Barat berdasarkan Keputusan Gubernur Provinsi DKI Jakarta Nomor : 1407/2009 tanggal 2 September 2009 tentang Pengesahan Akta Pembentukan PPRS Puri Garden Apartemen Kota Administrasi Jakarta Barat, dan bukti berupa Anggaran Rumah Tangga Perhimpunan Penghuni Rumah Susun, kedua surat bukti tersebut membuktikan bahwa PPRS Puri Garden Apartemen telah berbadan hukum. Sehingga secara hukum Para Penggugat berhak untuk mewakili dan memperjuangkan hak dan kepentingan seluruh Penghuni/Pemilik Rumah Susun Puri Garden Apartemen, oleh karenanya patut mendapat perhatian yang baik untuk kelangsungannya dan keberadaannya, agar Para Penghuni tidak diterlantarkan. Pertimbangan Majelis Hakim untuk hal ini tidak sesuai dengan pengaturan dalam UU Rumah Susun, pembentukan PPPSRS terdapat 2 (dua) Pasal dalam UU Rumah Susun yaitu Pasal 74 dan Pasal 75 UU Rumah Susun. 
Pembentukan PPPSRS wajib dibentuk oleh pemilik, seseorang dianggap sebagai pemilik apabila telah memenuhi proses peralihan hak atas tanah atau sarusun. Pemilik rumah susun terlebih dahulu melakukan pemenuhan proses jual beli kepemilikan rumah susun melalui penandatanganan AJB di hadapan PPAT untuk sarusun, namun penandatanganan AJB dapat berjalan asalkan penjual/ developer telah menyelesaikan pengurusan sertipikat laik fungsi dan sertipikat hak milik atas sarusun dan dokumen lainnya. Apabila ketentuan Pasal 44 UU Rumah Susun tidak terpenuhi, maka pembentukan PPPSRS tidak dapat ditentukan waktunya karena pembentukan PPPSRS tergantung pada niat baik penjual/ developer. Pembeli sarusun melalui pembuatan PPJB dengan penjual/developer dan telah dilakukan pembayaran secara lunas oleh pembeli serta telah dilakukan serah terima sarusun, namun selama belum dilakukan penandatanganan AJB sebagai dasar pemilik sarusun mendapatkan SHM sarusun yang diterbitkan oleh Kantor Pertanahan Kabupaten/Kota setempat. Selama proses itu belum terjadi, untuk itu kedudukan pembeli belum sebagai pemilik dan tidak dapat mendirikan PPPSRS. Pemilik sarusun yang membentuk PPPSRS yakni pembeli yang melakukan jual beli melalui AJB pertama kali dengan penjual/developer atau melalui pembelian dari pemilik sebelumnya, pemberian hibah atau peristiwa hukum pewarisan.

Undang-Undang Nomor 20 Tahun 2011 tentang Rumah Susun belum memiliki peraturan pelaksanaan, namun dalam Pasal 118 huruf bUU Rumah Susun masih memberlakukan peraturan pelaksanaan dari Undang-Undang Nomor 16 Tahun 1985 tentang Rumah Susun sepanjang tidak bertentangan atau belum diganti dengan peraturan pelaksanaan yang baru berdasarkan Undang-Undang Nomor 20 Tahun 2011 tentang Rumah Susun. Maka peraturan pelaksanaannya mengacu pada ketentuan Peraturan Pemerintah Nomor 4 Tahun 1988 tentang Rumah Susun (selanjutnya disebut PP No. 4 Tahun 1988) dan Keputusan Menteri Negara Perumahan Rakyat Nomor 06/KPTS/BPK4N/1995 tentang Pedoman Pembuatan Akta Pendirian, Anggaran Dasar dan Anggaran Rumah Tangga Perhimpunan Penghuni Rumah Susun. Pada bagian umum angka 7 penjelasan PP 
No. 4 Tahun 1988 menyebutkan, bahwa “... pembentukan perhimpunan penghuni wajib dilakukan dengan akta, dan baru sah berkedudukan sebagai badan hukum setelah disahkan oleh Bupati atau Walikota atau di Daerah Khusus Ibukota Jakarta oleh Gubernur Kepala Daerah...", dalam ketentuan tersebut mewajibkan pembentukan PPPSRS dilakukan dengan akta dan status badan hukum akan lahir setelah mendapat pengesahan dari instansi tersebut.

Kedudukan PPRS Puri Garden Apartemen sebagai penggugat dalam Putusan PN Jakarta Barat Nomor 089/Pdt.G/2013/PN.Jkt.Bar, dengan melihat ketentuan Pasal 44 dan Pasal 74 UU Rumah Susun tidak memiliki legal standing dalam perkara ini karena para pembeli rumah susun Puri Garden Apartemen belum dilakukan penandatanganan AJB dengan penjual/developer, untuk itu kedudukan PPRS Puri Garden Apartemen sebagai PPPSRS tidak sah. Keputusan Gubernur Provinsi DKI Jakarta No. 1407/2009 tanggal 2 September 2009 tentang Pengesahan Akta Pembentukan PPRS Puri Garden Apartemen Kota Administrasi Jakarta Barat, proses pembentukan perhimpunan penghuni telah memenuhi ketentuan PP No. 4 Tahun 1988. Namun peraturan pelaksanaan tidak boleh bertentangan dengan UU Rumah Susun, sehingga PPRS Puri Garden Apartemen sebagai penggugat tidak memiliki legal standing, untuk itu penulis tidak setuju terhadap amar putusan Majelis Hakim yang memberikan hak dan kuasa dalam penyelesaian tanah pada rumah susun kepada pembeli dan memerintahkan Para Tergugat atau siapa saja untuk mengosongkan dengan baik atas tanah Hak Guna Bangunan (HGB) No. 3023, No. 3187 dan No.3158 atas nama PT. Mitra Prima Sejahtera dan menyerahkannya kepada Para Penggugat, seharusnya hak dan kuasa itu diberikan kepada Tergugat IV yang masih memiliki itikad baik untuk menyelesaikan perkara rumah susun Puri Garden Apartemen dengan bantuan para pembeli yang belum menjadi pemilik.

\section{Kesimpulan}

Perjanjian pengikatan jual beli yang digolongkan sebagai perjanjian bersyarat karena sudah menyentuh pokok-pokok perjanjian dan telah menimbulkan 
akibat hukum. Penjual/developer yang akan menjadikan objek PPJB sebagai jaminan, dasar keabsahan pembuatan APHT atas sertipikat HGB pada rumah susun yang telah dilakukan PPJB harus memenuhi ketentuan Pasal 11 UUHT dan memperhatikan ketentuan Pasal 10 ayat (3) huruf d Permen PUPR No. 11/ PRT/M/2019, bahwa tanah dan/atau bangunan menjadi agunan atau akan dijadikan agunan harus meminta persetujuan kepada pembeli. Karena janjijanji yang terdapat dalam APHT yang didaftarkan akan mengikat pihak ketiga, objek yang sudah dibebani hak tanggungan, maka kewenangan pemberi hak tanggungan menjadi terbatas.

Bentuk perlindungan hukum bagi pembeli satuan rumah susun dapat berupa perlindungan hukum preventif yang diterapkan dalam peraturan perundangundangan antara lain: (i) Pasal 98 UU Rumah Susun; (ii) Pasal 12 Permen PUPR No. 11/PRT/M/2019; (iii) Pasal 1320 BW; dan (iv) SEMA No. 4 Tahun 2016 namun hanya sebagai pedoman hakim dalam memberikan putusan, dan perlindungan hukum represif yakni perlindungan terakhir berbentuk sanksi yang diberikan setelah terjadi sengketa atau terjadinya pelanggaran dan perlindungan di pengadilan, diaplikasikan dalam Pasal 110 UU Rumah Susun dan Pasal 117 UU Rumah Susun. Setelah pembuatan PPJB yang sah memenuhi ketentuan Pasal 43 UU Rumah Susun, penjual/developer yang menjadikan objek PPJB sebagai jaminan tanpa persetujuan pembeli, bentuk perlindungan yang diberikan berupa perlindungan represif, namun penyelesaian sengketa dapat dilakukan melalui jalur litigasi maupun non-litigasi.

\section{Daftar Bacaan}

\section{Buku}

Agus Yudha Hernoko, Hukum Perjanjian Asas Proporsionalitas Dalam Kontrak Komersial (Kencana Prenada Media Group 2014).

Celine Tri Siwi Kristiyani, Hukum Perlindungan Konsumen (Sinar Grafika 2009).

Handri Raharjo, Sistem Hukum Indonesia: Ketentuan-Ketentuan Hukum Indonesia Dan Hubungannya Dengan Hukum Internasional (Pustaka Yustisia 2018). 
Moch Isnaeni, Pengantar Hukum Jaminan Kebendaan (PT Revka Petra Media 2016).

Oemar Moechthar, Dinamika Hukum Agraria Indonesia Dalam Rangka Memperingati 70 Tahun Guru Kami, Prof. Dr. Sri Hajati, S.H., M.S. (Kencana 2020).

Philipus M. Hadjon, Pelindungan Hukum Bagi Rakyat Indonesia (Bina Ilmu 1987).

\section{Karya Ilmiah}

Kadek Deddy Permana, 'Keabsahan Pre Project Selling' (Universitas Airlangga 2020).

Philipus M. Hadjon, 'Eksistensi Dan Fungsi Pejabat Pembuat Akta Tanah (PPAT) Serta Figur Hukum Akta PPAT’ [1996] Fakultas Hukum Universitas Airlangga.

\section{Jurnal}

Urip Santoso, ‘Hak Guna Bangunan Atas Hak Pengelolaan' [2011] ADIL:Jurnal Hukum.

How to cite: Nahdlotul Fadilah, 'Keabsahan Pembuatan Akta Pemberian Hak Tanggungan Atas Sertipikat Hak Guna Bangunan Pada Rumah Susun Yang Telah Dilakukan Perjanjian Pengikatan Jual Beli' (2021) Vol. 4 No. 3 Notaire. 